\title{
Catabolic Pathways for Glucose, Glycerol and 6-Phosphogluconate in Mycobacterium leprae grown in Armadillo Tissues
}

\author{
By P. R. WHEELER \\ National Institute for Medical Research, Mill Hill, London NW7 1AA, U.K.
}

(Received 23 July 1982; revised 8 November 1982)

\begin{abstract}
With radioisotopes, it was shown that suspensions of Mycobacterium leprae oxidized glycerol, 6phosphogluconate, glucose, glucose 6-phosphate, and, at a low rate, gluconate, to $\mathrm{CO}_{2}$. The incubation period in these experiments was usually $20 \mathrm{~h}$, but after $140 \mathrm{~h}$ up to five times more glucose and gluconate had been converted to $\mathrm{CO}_{2}$. Studies with differentially labelled glucose indicated that glycolysis and the hexose monophosphate pathway were used for glucose dissimilation.

Key enzymes of glycolysis, the hexose monophosphate pathway and glycerol catabolism were detected in cell-free extracts from purified $M$. leprae, but phosphoketolase, Entner-Doudoroff pathway activity and gluconate kinase were absent. All these enzymes were present also in hosttissue, but biochemical evidence is presented which indicates that all enzymes detected in extracts from $M$. leprae were authentic bacterial enzymes. Additionally, they could all be detected in extracts of $M$. leprae prepared by treatment with $\mathrm{NaOH}$ in which host enzymes adsorbed to $M$. leprae are inactivated.
\end{abstract}

\section{INTRODUCTION}

When the literature on the intermediary metabolism of mycobacteria was reviewed (Ramakrishnan et al., 1972; Ratledge, 1976), nothing was known about the carbon metabolism of Mycobacterium leprae. Glutamate decarboxylase (Prabhakaran \& Braganca, 1962) and $o$ diphenoloxidase (Prabhakaran, 1973) had been identified as enzymes of $M$. leprae, but their metabolic significance was (and is) not known.

Mycobacterium leprae has not been cultured, but the bacteria may be obtained from experimentally infected nine-banded armadillos (Dasypus novemcinctus Linn.). The discovery that armadillos develop a systemic infection (Kirchheimer \& Storrs, 1971) has made available two to three orders of magnitude more leprosy bacilli for experimental work than were available from human biopsies, the previous best source. With $M$. leprae from armadillos, some glycosidases (Matsuo \& Skinsnes, 1974; Wheeler et al., 1982), acid phosphatase (Wheeler et al., 1982), $\gamma$-glutamyl transpeptidase (Shetty et al., 1981) and enzymes which catabolize the breakdown of oxygen-free radicals (Kusunose et al., 1980; Wheeler \& Gregory, 1980) have been identified as enzymes of $M$. leprae.

It has been established that glucose (Khanolkar, 1982) and possibly glycerol (S. R. Khanolkar, personal communication) are taken up by $M$. leprae, and preliminary evidence indicates that glycolysis and the hexose monophosphate pathway (HMP) are involved in glucose metabolism (Wheeler, 1982). In this study, suspensions of $M$. leprae were incubated with carbohydrates to look for catabolism to $\mathrm{CO}_{2}$, and further key enzymes were assayed in extracts of purified $M$. leprae. Properties such as the effect of inhibitors, affinity for substrates, and electrophoretic

\footnotetext{
Abbreviations: DHAP, Dihydroxyacetone phosphate; EDP, Entner-Doudoroff pathway; HMP, hexose monophosphate pathway; ITP, inosine triphosphate; NBT, nitro blue tetrazolium; PMS, methylphenazonium methosulphate; UM-P, 4-methylumbelliferyl phosphate.
} 
mobility of enzymes were studied, mainly to compare $M$. leprae enzymes with those from hosttissue. It is essential to make such comparisons because enzymes detected in extracts of $M$. leprae could be contaminating activities derived from host-tissue (Wheeler et al., 1982; Wheeler $\&$ Gregory, 1980). Differences in properties would provide evidence for authentic $M$. leprae enzymes.

Initially, the catabolism of glucose by glycolysis and 'alternative' pathways, e.g. HMP, Entner-Doudoroff Pathway (EDP), as well as glycerol catabolism was studied. The observation of remarkably high levels of 6-phosphogluconate dehydrogenase and transketolase (Wheeler, 1982) led to experiments with 6-phospho[ $\left[{ }^{14} \mathrm{C}\right]$ gluconate and $\left[{ }^{14} \mathrm{C}\right]$ gluconate as possible substrates for $M$. leprae. There are two problems in the experiments in which suspensions of $M$. leprae are incubated with sugar phosphates. Experiments were designed so as to overcome possible problems due to the presence of different uptake systems for sugars and sugarphosphates and to the degradation of sugar-phosphates by acid phosphatase.

\section{METHODS}

Mycobacteria. Mycobacterium leprae and Mycobacterium lepraemurium were harvested from armadillo liver or lymph node, and mouse liver, respectively (Wheeler \& Gregory, 1980). Highly purified suspensions (Report, 1979) were prepared by tissue homogenization followed by treatment with DNAase and Percoll (Pharmacia) densitycentrifugation (only for $M$. leprae). When cell-free extracts were required, suspensions of $M$. leprae were further purified on an aqueous two-phase system [7 g Dextran T500 (Pharmacia); $4.9 \mathrm{~g}$ polyethylene glycol $6000 ; 0.1 \mathrm{~g}$ polyethylene glycol monopalmitate; $0.01 \mathrm{M}-\mathrm{NaCl} ; 0.01 \mathrm{M}$-potassium phosphate ( $\mathrm{pH} \mathrm{6.9)}$; bacteria suspended in buffered Tween (see below); and distilled water to $100 \mathrm{~g}$ in total (Report, 1979)]. Mycobacterium phlei NCTC 10266 was grown as described previously (Wheeler \& Gregory, 1980). Cell-free extracts of mycobacteria were prepared by ultrasonication and centrifugation (Wheeler \& Gregory, 1980). Since thiols are required to preserve some enzyme activities, some suspensions of $\boldsymbol{M}$. leprae organisms were disrupted in sonication buffer (Wheeler \& Gregory, 1980) containing $0 \cdot 1 \mathrm{~mm}$-dithiothreitol (DTT) and enzymes were assayed in cell-free extracts prepared in the presence of (as well as without) this thiol reagent.

$\mathrm{NaOH}$-treatment of $\mathrm{M}$. leprae. Suspensions of pure $\mathrm{M}$. leprae were incubated at $25^{\circ} \mathrm{C}$ in $1 \mathrm{M}-\mathrm{NaOH}$ for $1 \mathrm{~h}$; after neutralization with 2 M-HEPES, a cell-free extract was prepared (Wheeler \& Gregory, 1980). Alternatively, the bacterial suspensions were incubated at $25^{\circ} \mathrm{C}$ in $0.5 \mathrm{M}-\mathrm{NaOH}$ for $30 \mathrm{~min}$; after neutralization they were washed three times and suspended in buffered Tween $80[0 \cdot 1 \%(\mathrm{w} / \mathrm{v})$ Tween $80 \mathrm{in} 1.5 \mathrm{~mm}-\mathrm{MES}, \mathrm{pH} 7 \cdot 0]$. Such suspensions were used in some incubations with radioisotopes.

EDTA-treatment of $M$. leprae. Immediately after the DNAase step in purification, EDTA (potassium salt) was added to a final concentration of $4 \mathrm{mM} .1 \mathrm{~mm}-\mathrm{Mg}^{2+}$ was already present at this stage (Report, 1979). Suspensions were incubated for $20 \mathrm{~min}$ before removing the bacteria by centrifugation at $10000 \mathrm{~g}$ for $10 \mathrm{~min}$ and continuing the purification scheme. Extracts free of organisms were prepared as described above, from the purified bacteria.

Extracts of armadillo tissues. Liver and lymph node tissue from uninfected armadillos was homogenized in $50 \mathrm{~mm}$-phosphate $\left(\mathrm{Na}_{2} \mathrm{HPO}_{4} / \mathrm{KH}_{2} \mathrm{PO}_{4}, \mathrm{pH} 7 \cdot 5\right)$ buffer with $1 \mathrm{mM}-\mathrm{MgCl}_{2}$ (Brock, 1969) for use in assays. Extracts of liver prepared as described previously (Wheeler \& Gregory, 1980) referred to here as 'EDTA-liver extract'; extracts free of $M$. leprae from infected armadillo livers (homogenized in Tris; pH 8.7) prepared by the method of Wheeler \& Gregory (1980) were used, only where described in Results.

Chromatography. Bio-Gel P2 was equilibrated with distilled water and distilled water was used as an eluate to separate mixtures of glucose and gluconate (Brown, 1970). In the past, anion-exchange chromatography had been used to separate mixtures of sugar-phosphates, but not including 6-phosphogluconate (Benson, 1957). In this study, columns of volume $1 \mathrm{ml}$ for analytical work, and $10 \mathrm{ml}$ for preparative work, were made with Dowex-2 (200-400 mesh, $8 \%$ cross-linked; from Sigma). They were washed with 2.5 column volumes (vol.) water, charged with $2.5 \mathrm{vol} .1 \mathrm{M}-\mathrm{HCl}$, then washed with water until free of chloride. Using 2.5 vol. eluent, glucose was eluted with water, gluconate and glucose 6-phosphate with $0.15 \mathrm{M}-\mathrm{NaCl}$, and 6-phosphogluconate with $0.05 \mathrm{M}-\mathrm{HCl}$ in $0.15 \mathrm{M}$ $\mathrm{NaCl}$. In each case, no radioactivity remained in the eluate after $2.5 \mathrm{vol}$. had been eluted through the column. Paper-chromatography with propan-2-ol/distilled water $(4: 1, \mathrm{v} / \mathrm{v})$ was also used to separate the sugars and phosphates (Menzies \& Seakins, 1969).

Radioisotopes. Radioisotopes (all ${ }^{14} \mathrm{C}$ ) were obtained from Amersham. $\left[{ }^{14} \mathrm{C}\right] \mathrm{Gluconate}$ and 6-phospho $\left[{ }^{14} \mathrm{C}\right] \mathrm{glu}$ conate were prepared thus: $0 \cdot 2 \mu \mathrm{mol} \mathrm{D}-\left[\mathrm{U}^{-1}{ }^{14} \mathrm{C}\right]$ glucose 6 -phosphate $\left(279 \mathrm{mCi} \mathrm{mmol}^{-1} ; 10 \cdot 3 \mathrm{GBq} \mathrm{mmol}^{-1}\right) \mathrm{was}^{-}$ added to $0.4 \mu \mathrm{mol} \mathrm{NADP}$ and $4 \mu \mathrm{mol}$ triethanolamine (adjusted to $\mathrm{pH} 7.6$ with $\mathrm{HCl}$ ) and incubated at $25^{\circ} \mathrm{C}$ for $30 \mathrm{~min}$ with $0.25 \mathrm{U}$ yeast glucose-6-phosphate dehydrogenase (Sigma). The volume at this stage was $500 \mu \mathrm{l}$. Yield of 6-phospho $\left[{ }^{14} \mathrm{C}\right]$ gluconate (judged by $A_{340}$ ) was $80-85 \%$. If $\left[{ }^{14} \mathrm{C}\right]$ gluconate was required, $20 \mu \mathrm{l} \mathrm{M}-\mathrm{Tris} / \mathrm{HCl}$, pH 9.2 and 1 U Escherichia coli alkaline phosphatase (Sigma) were added and the reaction mixture $(523 \mu \mathrm{l})$ was 
incubated at $37^{\circ} \mathrm{C}$ for $30 \mathrm{~min}$. All available phosphate was removed from glucose 6-phosphate and 6phosphogluconate as judged by the assay for inorganic phosphate (Ames, 1966). The $\left[{ }^{14} \mathrm{C}\right]$ gluconate was separated from $\left[{ }^{14} \mathrm{C}\right]$ glucose on a Bio-Gel P2 column (Brown, 1970). 6-Phospho[ $\left[{ }^{14} \mathrm{C}\right]$ gluconate was separated from $\left[{ }^{1+C} \mathrm{C}\right]$ glucose 6-phosphate on a Dowex-2 column, and judged to be pure by rechromatography or paper chromatography.

Incubations of $M$. leprae with radioisotopes. Mycobacteria ( 0.5 to $1.4 \mathrm{mg}$ dry wt) were incubated with ${ }^{1+} \mathrm{C}$-labelled substrate $(1 \mu \mathrm{Ci} ; 0 \cdot 02$ to $0 \cdot 1 \mathrm{mM})$, $\mathrm{HEPES}(50 \mathrm{~mm}), \mathrm{MgSO}_{4}(1 \mathrm{mM})$, and $\mathrm{K}_{2} \mathrm{HPO}_{4}(5 \mathrm{~mm})$, adjusted to $\mathrm{pH} 7 \cdot 0$ with $\mathrm{KOH}$. Additionally, $50 \mathrm{U}$ penicillin $\mathrm{ml}^{-1}$ could be added as it had no observable effects. This prevented growth of any chance contamination in the incubation mixtures. Mixtures $(200 \mu \mathrm{l})$ were incubated in Warburg Flasks at $34^{\circ} \mathrm{C}$. The centre well contained $400 \mu \mathrm{l} 1 \mathrm{M}-\mathrm{NaOH}$ to absorb $\mathrm{CO}_{2}$ evolved from oxidation of the substrate. Reactions were stopped by addition of $0.1 \mathrm{ml} 1.5 \mathrm{M}-\mathrm{H}_{2} \mathrm{SO}_{4}$ from a side-arm: $1 \mathrm{~h}$ later the $\mathrm{NaOH}$ was added to 'Instagel' (Packard)/distilled water $(10: 3, \mathrm{v} / \mathrm{v})$ for scintillation counting at $8^{\circ} \mathrm{C}$. Bacteria were collected and washed by centrifugation and resuspension until the supernatant was free of radioactivity. The final pellet was incubated for $1 \mathrm{~h}$ in Soluene-350 (Packard) at $37^{\circ} \mathrm{C}$, then $10 \mathrm{ml}$ Dimilume-30 (Packard) was added. The amount of radioactivity assimilated was estimated by scintillation counting of this pellet. The term 'uptake' has been used for the total of radioactivity assimilated plus radioactivity in the $\mathrm{CO}_{2}$ evolved. Results are expressed as d.p.m. (mg dry wt mycobacteria $)^{-1}$; when pure $M$. leprae organisms are dried and weighed, $10^{10}$ bacteria weigh $1 \mathrm{mg}(\mathrm{R}$. J. W. Rees, personal communication). The same relationship between numbers and acid fast bacilli has been deduced for other mycobacteria in this report. Controls contained either no bacteria, or, for determination of assimilation, heat-killed $\left(100^{\circ} \mathrm{C}, 15 \mathrm{~min}\right)$ bacteria. In the results, d.p.m. in controls are always subtracted.

Enzyme assays and enzyme nomenclature. All enzymes were assayed at $22^{\circ} \mathrm{C}$ and a few were assayed also at $34{ }^{\circ} \mathrm{C}$. The incubation volume for all assays was $500 \mu$ l except when NADP was included as a coenzyme (not for a coupling enzyme) for the enzyme being assayed; in this case the volume was either $500 \mu \mathrm{l}$, or $50 \mu \mathrm{l}$ and, after the end of the incubation, NADPH formed was detected by a cycling assay (Lilius et al., 1979). When the cycling method was not used, change of $A_{340}$ was observed for incubations including NADP, and change of $A_{340}$ was always observed for incubations including NADH or NADPH.

To minimize background readings, ATP and ADP were obtained from equine muscle and phosphoenolpyruvate as a tricyclohexammonium salt was used (all from Sigma): these details were essential. Other substrates with an acidic group were supplied (from Sigma) as sodium salts unless otherwise stated.

Hexokinase (EC 2.7.1.1; ATP:D-hexose 6-phosphotransferase) was assayed by incubating extracts with $0.64 \mathrm{mM}-\mathrm{ATP}, 20 \mathrm{~mm}$-D-hexose, $8 \mathrm{mM}-\mathrm{MgCl}_{2}$ and $40 \mathrm{~mm}$-triethanolamine (adjusted to $\mathrm{pH} 7.6$ with $\mathrm{HCl}$ ) plus a coupling mixture consisting of $0.4 \mathrm{~mm}-\mathrm{NADH}, 0.71 \mathrm{~mm}$-phosphoenolpyruvate and lactate dehydrogenase/pyruvate kinase mixture (Sigma; $13 \mathrm{U} \mathrm{ml}^{-1}$ and $17 \mathrm{U} \mathrm{ml}^{-1}$, respectively); this allowed for continuous detection of ADP production (Bergmeyer et al., 1974). Glucose 6-phosphate $(0 \cdot 1 \mathrm{M})$, an inhibitor of hexokinase (Goldberg et al., 1968), was added to controls. Alternatively, phosphorylation of glucose by hexokinase could be measured in extracts with triethanolamine ( $40 \mathrm{~mm}$, adjusted to $\mathrm{pH} 7.6$ with $\mathrm{HCl}), 20 \mathrm{~mm}$-glucose, $8 \mathrm{~mm}-\mathrm{MgCl}_{2}, 0.64 \mathrm{~mm}-\mathrm{ATP}$, $0.91 \mathrm{~mm}-\mathrm{NADP}$ and glucose-6-phosphate dehydrogenase from yeast (Sigma; $0.55 \mathrm{U} \mathrm{ml}^{-1}$ ).

Phosphohexoisomerase (EC 5.3.1.9; D-glucose-6-phosphate ketol-isomerase) was assayed in extracts either with $1.4 \mathrm{~mm}$-fructose 6-phosphate as substrate (Bergmeyer et al., 1974) in $85 \mathrm{~mm}$-triethanolamine (adjusted to $\mathrm{pH} 7.6$ with $\mathrm{HCl}$ ), $6.8 \mathrm{~mm}-\mathrm{MgCl}_{2}, 0.39 \mathrm{~mm}-\mathrm{NADP}$ and glucose-6-phosphate dehydrogenase from yeast (Sigma; $0.46 \mathrm{U} \mathrm{ml}^{-1}$ ), or with $1.4 \mathrm{~mm}$-glucose 6 -phosphate as substrate, in which case $6.8 \mathrm{~mm}-\mathrm{MgCl}_{2}$ and $85 \mathrm{~mm}^{-}$ triethanolamine (adjusted to $\mathrm{pH} 7.6$ with $\mathrm{HCl}$ ) were included in the assay mixture, together with $2 \mathrm{U}$ rabbit muscle phosphofructokinase (Sigma) ml-1, $1 \cdot 1 \mathrm{~mm}$-ATP, $0 \cdot 4 \mathrm{~mm}-\mathrm{NADH}, 0 \cdot 71 \mathrm{~mm}$-phosphoenolpyruvate, and a lactate dehydrogenase/pyruvate kinase mixture from rabbit muscle (Sigma; $13 \mathrm{U} \mathrm{ml}^{-1}$ and $17 \mathrm{U} \mathrm{ml}^{-1}$, respectively).

Phosphofructokinase (EC 2.7.1.11; ATP:D-fructose-6-phosphate 1-phosphotransferase) was assayed by a modification of the method of Ling et al. (1966). The incubation mixture was $80 \mathrm{~mm}$-Tris (adjusted to $\mathrm{pH} 8.5 \mathrm{with}$ $\mathrm{HCl}$ ), $1 \mathrm{~mm}-\mathrm{MgCl}_{2}, 4 \mathrm{~mm}-\mathrm{KCl}, 5 \mathrm{~mm}$-fructose 6-phosphate, $0.92 \mathrm{~mm}-\mathrm{ATP}, 1 \mathrm{~mm}-\mathrm{DTT}, 0.23 \mathrm{~mm}-\mathrm{NADH}$, $60 \mathrm{U}$ rabbit muscle aldolase (Sigma) $\mathrm{ml}^{-1}$ and $\alpha$-glycerophosphate dehydrogenase/triose phosphate isomerase mixture (Sigma, $1.6 \mathrm{U} \mathrm{ml}^{-1}$ and $16 \mathrm{U} \mathrm{ml}^{-1}$, respectively).

Aldolase (EC 4.1.2.13; D-fructose-1,6-bisphosphate D-glyceraldehyde-3-phosphate lyase) was assayed by incubating extracts with $1 \mathrm{~mm}$-fructose 1,6-diphosphate, $0.2 \mathrm{~mm}-\mathrm{NADH}, 80 \mathrm{~mm}$-triethanolamine (adjusted to $\mathrm{pH} 7.6$ or $\mathrm{pH} 8.6$ with $\mathrm{HCl}$ ) and an $\alpha$-glycerophosphate dehydrogenase/triose phosphate isomerase mixture from rabbit muscle (Sigma; $1.6 \mathrm{U} \mathrm{ml}^{-1}$ and $16 \mathrm{U} \mathrm{ml}^{-1}$, respectively). Schiffs base formation with aldolase and dihydroxyacetone phosphate was carried out by a modification of the method of Grazi et al. (1962); to $3 \mathrm{mM}^{-}$ dihydroxyacetone phosphate in $0 \cdot 1 \mathrm{M}$-potassium phosphate, $\mathrm{pH} 6 \cdot 0$, and $1 \cdot 12 \mathrm{mg}$ protein ( $\mathrm{ml}$ cell-free extract) ${ }^{-1}$ (armadillo liver or $M$. leprae), $2.8 \mathrm{M}$-sodium borohydride was added in four $5 \mu \mathrm{l}$ amounts so that the final concentration was $0.14 \mathrm{M}$. The $\mathrm{pH}$ was maintained at 6.0 by addition of $2.5 \mathrm{M}$-acetic acid when required. After 30 min, the mixtures were desalted using an Amicon CF25 ultrafiltration cone $\left(700 \mathrm{~g}, 4^{\circ} \mathrm{C}\right)$. All stages were carried out at $0-4{ }^{\circ} \mathrm{C}$. 
Glyceraldehyde-3-phosphate dehydrogenase (EC 1.2.1.12; D-glyceraldehyde-3-phosphate: NAD ${ }^{+}$ oxidoreductase (phosphorylating), was assayed (Bergmeyer et al., 1974) by incubating extracts with 82.5 mM-triethanolamine (adjusted to pH 7.6 with $\mathrm{HCl}$ ), $6 \mathrm{~mm}$-3-phosphoglycerate (cyclohexammonium salt), 0.9 mM-EDTA (sodium salt), $1.7 \mathrm{~mm}-\mathrm{MgSO}_{4}, 0.2 \mathrm{mM}-\mathrm{NADH}, 1.1 \mathrm{~mm}-\mathrm{ATP}$, and 3-phosphoglycerate kinase from yeast (Sigma; grade free of glyceraldehyde-3-phosphate dehydrogenase; $15 \mathrm{U} \mathrm{ml}^{-1}$ ).

Pyruvate kinase (EC 2.7.1.40; ATP : pyruvate 2- $O$-phosphotransferase) was assayed (Bergmeyer et al., 1974) by incubating extracts in $80 \mathrm{~mm}$-triethanolamine (adjusted to $\mathrm{pH} 7.6$ with $\mathrm{HCl}$ ), $0.54 \mathrm{~mm}$-phosphoenolpyruvate, cyclohexammonium salt, $2.5 \mathrm{~mm}-\mathrm{MgSO}_{4}, 10 \mathrm{~mm}-\mathrm{KCl}, 4 \cdot 7 \mathrm{mM}-\mathrm{ADP}$ (adjusted to neutrality with $\mathrm{KOH}$ ), $0 \cdot 2 \mathrm{~mm}-$ NADH and lactate dehydrogenase [LDH-1(H4) isoenzyme from beef heart], free of pyruvate kinase activity (Sigma; 9.2 $\mathrm{U} \mathrm{ml}^{-1}$ ).

Glucose-6-phosphate dehydrogenase (EC 1.1.1.49; D-glucose-6-phosphate:NADP+ 1-oxidoreductase) was assayed (Bergmeyer et al., 1974) by incubating extracts in $80 \mathrm{~mm}$-triethanolamine (adjusted to $\mathrm{pH} 7.6 \mathrm{with} \mathrm{HCl}$ ), $7 \mathrm{mM}-\mathrm{MgCl}_{2}, 1 \mathrm{mM}$-glucose 6-phosphate and $0 \cdot 39 \mathrm{~mm}-\mathrm{NADP}$.

6-Phosphogluconate dehydrogenase (EC 1.1.1.44; 6-phospho-D-gluconate: NADP+ 2-oxidoreductase (decarboxylating) was assayed (Bergmeyer et al., 1974) by incubating extracts in 80 mM-triethanolamine (adjusted to pH 7.6 with $\mathrm{HCl}$ ), $3.5 \mathrm{~mm}-\mathrm{MgCl}_{2}, 2.7 \mathrm{~mm}-6$-phosphogluconate and $3.4 \mathrm{~mm}-\mathrm{NADP}$. For this enzyme and glucose6-phosphate dehydrogenase (above), NADPH formed was usually assayed by the cycling method (Lilius et al., 1979).

Transketolase (EC 2.2.1.1; sedoheptulose-7-phosphate :D-glyceraldehyde-3-phosphate glycolaldehydetransferase) was assayed by the method of Horecker et al. (1956), modified in that glyceraldehyde 3-phosphate formed was monitored continuously by the addition of $0 \cdot 1 \mathrm{mM}-\mathrm{NADH}$ and $\alpha$-glycerophosphate dehydrogenase/triose phosphate isomerase mixture (Sigma; $0.8 \mathrm{U} \mathrm{ml}^{-1}$ and $8 \mathrm{U} \mathrm{ml}^{-1}$, respectively) to the assay mixture of $10 \mathrm{mM}^{-}$ glycylglycine buffer (adjusted to $\mathrm{pH} 7.6$ with $\mathrm{HCl}$ ), $6 \mathrm{~mm}$-cysteine (adjusted to pH 7.6 with $\mathrm{NaOH}$ ), $2 \mathrm{mM}-\mathrm{MgCl}_{2}$, $0 \cdot 1 \mathrm{~mm}$-thiamine pyrophosphate, $0.8 \mathrm{~mm}$-xylulose 5-phosphate, and either $0.8 \mathrm{~mm}$-ribose 5-phosphate or $1.0 \mathrm{~mm}$ erythrose 4-phosphate.

$\alpha$-Glycerophosphate dehydrogenase (EC 1.1.1.8; sn-glycerol-3-phosphate: NAD ${ }^{+}$2-oxido-reductase) was assayed in extracts either by the method described by Bergmeyer et al. (1974) with 287 mM-triethanolamine (adjusted to $\mathrm{pH} 7.6$ with $\mathrm{HCl}$ ), dihydroxyacetone phosphate $(0.007 \mathrm{~mm}$ to $2.10 \mathrm{mM}$; preliminary kinetic studies were done), and $0.2 \mathrm{~mm}-\mathrm{NADH}$, or by the method of Winder \& Brennan (1966), in which the forward reaction was assayed by the inclusion of a tetrazolium salt, thiazolyl blue (MTT; Sigma) at $0.08 \mathrm{mM}$ and $0 \cdot 11 \mathrm{mM}$-methylphenazonium methosulphate (PMS) with extracts, $100 \mathrm{~mm}-\alpha$-glycerophosphate, $0 \cdot 2 \mathrm{M}$-phosphate buffer $\left(\mathrm{Na}_{2} \mathrm{HPO}_{4} / \mathrm{KH}_{2} \mathrm{PO}_{4}, \mathrm{pH} 7\right), 0 \cdot 167 \mathrm{~mm}-\mathrm{NAD}$ or NADP, and $10 \mathrm{~mm}-\mathrm{KCN}$. Glycerol dehydrogenase was also assayed by substituting $100 \mathrm{~mm}$-glycerol for $\alpha$-glycerophosphate.

Phosphoketolase (EC 4.1.2.9; D-xylulose-5-phosphate:D-glyceraldehyde-3-phosphate-lyase (phosphate-acetylating) was assayed by the method of Goldberg et al. (1968), in which extracts were incubated with $40 \mathrm{~mm}$ phosphate $\left(\mathrm{Na}_{2} \mathrm{HPO}_{4} / \mathrm{KH}_{2} \mathrm{PO}_{4}, \mathrm{pH} 6.0\right), 10 \mathrm{~mm}$-glutathione (adjusted to $\mathrm{pH} 6$ with $\mathrm{NaOH}$ ), 10 mM-xylulose 5phosphate, $1 \mathrm{mM}$-EDTA (Na salt), $3 \mathrm{~mm}-\mathrm{MgCl}_{2}, 0.5 \mathrm{~mm}$-thiamine pyrophosphate; glyceraldehyde 3-phosphate was monitored continuously by the inclusion of $0.1 \mathrm{~mm}-\mathrm{NADH}$ and an $\alpha$-glycerophosphate dehydrogenase/triose phosphate isomerase mixture (Sigma; $0.8 \mathrm{U} \mathrm{ml}^{-1}$ and $8 \mathrm{U} \mathrm{ml}^{-1}$, respectively).

Glucuronate reductase (EC 1.1.1.19; L-gulonate: NADP+ 1-oxidoreductase) was assayed by incubating extracts with D-glucuronate and NADPH in conditions similar to those used by York et al. (1961). Extracts were buffered with $60 \mathrm{mM}$-HEPES (adjusted to $\mathrm{pH} 7.2$ with $\mathrm{KOH}$ ) or $50 \mathrm{~mm}$-Tris/glycine, pH $9.0,10 \mathrm{~mm}$-glucuronate and NADPH $(0.12 \mathrm{~mm}$ or $0.46 \mathrm{~mm})$ were included as substrates and assays were done with or without $1 \mathrm{~mm}-\mathrm{EDTA}$ (sodium salt).

Gluconokinase (EC 2.7.1.12; ATP:D-gluconate 6-phosphotransferase) and polyphosphate:D-gluconate 6-phosphotransferase (EC 2.7.1.X) were assayed by first incubating extracts (at $22^{\circ} \mathrm{C}$ or $34^{\circ} \mathrm{C}$ )

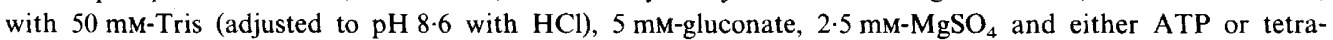
polyphosphate (Sigma) at $5 \mathrm{mM}$ (total volume was $500 \mu \mathrm{l})$. After this incubation, the mixture was heated at $60{ }^{\circ} \mathrm{C}$ for $3 \mathrm{~min}$ and $40 \mu \mathrm{l} 1 \mathrm{M}$-HEPES base, $30 \mu \mathrm{l} 80 \mathrm{mM}-\mathrm{NADP}$ and $0.1 \mathrm{U}$ 6-phosphogluconate (yeast; Sigma) were added and incubated at $22^{\circ} \mathrm{C}$ for $45 \mathrm{~min}$ (i.e. until no further NADPH was produced). NADPH was detected by reading directly $A_{340}$ (Szymona et al., 1969), or by taking samples for the cycling assay (Lilius et al., 1979).

Glucose oxidase (EC 1.1.3.4; $\beta$-D-glucose :oxygen 1-oxidoreductase) and glucose dehydrogenase (EC 1.1.1.47; $\beta$-D-glucose : NAD[P] $]^{+}$1-oxidoreductase) were assayed by methods used by Galante et al. (1963). $80 \mathrm{mM}$-Triethanolamine $/ \mathrm{HCl}(\mathrm{pH} \mathrm{8.6)}$ ) or $50 \mathrm{mM}-\mathrm{MES}(\mathrm{pH} \mathrm{6.6)}$ were used as buffers and the substrate was $16 \mathrm{mM}-$ D-glucose. To detect dehydrogenases, $1 \mathrm{mM}-\mathrm{NADP}$ or NAD was included; to detect glucose oxidase, $0.5 \mathrm{~mm}$ KCN and $0.113 \mathrm{~mm}$-2,6-dichlorophenolindophenol (sodium salt, Sigma) were included in place of coenzyme.

Enzymes of the EDP were assayed by a method (Kovachevich \& Wood, 1955) for 6-phosphogluconate dehydratase (EC 4.2.1.12; 6-phospho-D-gluconate hydrolyase) modified in that keto-deoxygluconate was replaced by 6-phosphogluconate $(50 \mathrm{~mm})$ and that the pyruvate formed was monitored continuously by the 
inclusion of $0.5 \mathrm{U}$ rabbit muscle lactate dehydrogenase (Sigma) $\mathrm{ml}^{-1}$ and $0.4 \mathrm{~mm}-\mathrm{NADH}$ : extract, $50 \mathrm{~mm}$-Tris (adjusted to $\mathrm{pH} 8.0$ with $\mathrm{HCl}$ ), $25 \mathrm{~mm}$-glutathione (adjusted to $\mathrm{pH} 8.0$ with $\mathrm{NaOH}$ ), lactate dehydrogenase and $\mathrm{NADH}$ were mixed and then $\mathrm{MnCl}_{2}$ was added to $0.1 \mathrm{~mm}$, then $10 \mathrm{~min}$ later the 6-phosphogluconate was added and fall in $A_{340}$ was read.

Enzyme activities are expressed as units (U) where one unit catalyses the conversion of $1 \mu$ mol substrate min $^{-1}$. Inhibitors (all Sigma) were added to extracts in assays before coupling enzymes and 5 min before substrates.

$P A G E$. Extracts were applied to $7 \%(\mathrm{w} / \mathrm{v})$ polyacrylamide gels at $\mathrm{pH} 9.0$ (Davis, 1964) to detect glucose-6phosphate dehydrogenase and at $\mathrm{pH} 6.5$ (Chang et al., 1979) to detect 6-phosphogluconate dehydrogenase. After electrophoresis, glucose-6-phosphate dehydrogenase was detected by the method of Mori et al. (1967). For detection of 6-phosphogluconate dehydrogenase, $10 \mathrm{~mm}$-6-phosphogluconate was used instead of glucose 6phosphate. Essentially, the methods involved adding nitro blue tetrazolium (NBT), PMS and KCN to the enzyme assay mixtures. Results were expressed as electrophoretic mobility relative to the mobility (1.00) of bromophenol blue.

Statistical analysis. A non-parametric test of significance (Nimmo \& Atkins, 1979), the Wilcoxon text (Colquhoun, 1971) was used for experiments with radioisotopes. Null hypotheses tested were : (i) $\mathrm{CO}_{2}$ evolution, and assimilation were equal in incubations with live bacteria and controls, (ii) proportions of $\left[1-1^{14} \mathrm{C}\right]$ and [6-14 $\mathrm{C}$ ]glucose converted to $\mathrm{CO}_{2}$ by $M$. leprae were equal, (iii) $\mathrm{CO}_{2}$ evolution and assimilation were not affected by treatments of $M$. leprae, or the addition of umbelliferyl phosphate or Casamino acids to incubations. Standard error of enzyme activity was calculated when four or more extracts of $M$. leprae were assayed.

\section{RESULTS}

\section{Catabolism of substrates by unbroken $M$. leprae}

$\left[\mathrm{U}-{ }^{14} \mathrm{C}\right]$ Glucose was taken up and catabolized to $\mathrm{CO}_{2}$ by suspensions of purified $M$. leprae. The addition of $10 \mathrm{~mm}$-4-methylumbelliferyl phosphate (UM-P) to incubations, or the use of $\mathrm{NaOH}$-treated suspensions did not $(P>0 \cdot 10)$ affect either assimilation or catabolism (Table 1$)$. In incubations with $\left[1-{ }^{14} \mathrm{C}\right]$ glucose, 3180 d.p.m. $\mathrm{CO}_{2} \mathrm{mg}^{-1}$ per $20 \mathrm{~h}$ were evolved and $36 \%$ of the substrate taken up was catabolized to $\mathrm{CO}_{2}$. With $\left[6^{-14} \mathrm{C}\right]$ glucose, 2600 d.p.m. $\mathrm{CO}_{2} \mathrm{mg}^{-1}$ per $20 \mathrm{~h}$ were evolved and $17 \%$ of the substrate taken up was catabolized to $\mathrm{CO}_{2}$. The proportion of glucose converted to $\mathrm{CO}_{2}$ was significantly higher $(P<0 \cdot 05)$ for $\left[1-{ }^{14} \mathrm{C}\right] \mathrm{glucose}$ than [6${ }^{14} \mathrm{C}$ lglucose, providing evidence for presence of the HMP. With the formula of Wood et al. (1963), it was calculated that $9 \cdot 3 \%$ of glucose 6-phosphate formed from glucose was metabolized via the HMP (pentose cycle in the terminology of Wood et al., 1963). [U-14 C]glycerol was also catabolized to $\mathrm{CO}_{2}$ by $M$. leprae (Table 1), but very high (>40000 d.p.m.) counts in the heatkilled bacteria made it impossible to detect significant uptake. The rate of $\mathrm{CO}_{2}$ production $(\mathrm{mg}$ $M$. leprae $)^{-1}$ was also determined as a percentage of the rate in $M$. lepraemurium and $M$. phlei. For [U $\left.{ }^{-14} \mathrm{C}\right]$ glucose it was $260 \%$ and $1 \cdot 2 \%$, respectively; for glycerol it was $20 \%$ compared with M. lepraemurium.

6-Phosphogluconate was oxidized to $\mathrm{CO}_{2}$ at a similar rate to glucose by $M$. leprae. However, the proportion of 6-phosphogluconate catabolized to $\mathrm{CO}_{2}$ was far greater than the proportion of glucose catabolized to $\mathrm{CO}_{2}$ (Table 1). When the concentration of 6-phosphogluconate in incubation mixtures was $0.02 \mathrm{mM}, 10 \%$ was hydrolysed $(\mathrm{mg} \mathrm{M} \text {. leprae })^{-1}$ per $20 \mathrm{~h}$. When $10 \mathrm{mM}-$ UM-P was added to incubations, the rate of oxidation of 6-phosphogluconate doubled (Table 1) and hydrolysis of 6-phosphogluconate was completely inhibited. While this represented a significant $(P<0.01)$ increase for the rate of oxidation, the rate of assimilation of 6phosphogluconate was not significantly different $(P>0 \cdot 10)$ in incubations with UM-P. NaOHtreated $M$. leprae oxidized to $\mathrm{CO}_{2}$ the same proportion of the 6-phosphogluconate taken up, but both assimilation $(P<0.05)$ and oxidation to $\mathrm{CO}_{2}(P<0.01)$ were significantly lower than with untreated $M$. leprae.

The proportion of glucose 6-phosphate taken up which was catabolized to $\mathrm{CO}_{2}$ by $M$. leprae was similar to the proportion for glucose, although the rate of assimilation of glucose 6phosphate was significantly lower $(P<0.05)$ than for glucose. NaOH-treatment of $M$. leprae did not affect assimilation or oxidation of glucose 6-phosphate, but incubation with $10 \mathrm{mM}-\mathrm{UM}$ $\mathrm{P}$ (Table 1$)$ inhibited oxidation significantly $(P<0.05)$, but affected assimilation less $(P<$ $0 \cdot 10)$. Limited hydrolysis $\left(6 \% \mathrm{mg}^{-1}\right.$ per $\left.20 \mathrm{~h}\right)$ of $0.02 \mathrm{~mm}$-glucose 6-phosphate by $M$. leprae 


\section{Table 1. Metabolism of $U^{-14} C$-labelled carbon sources by $M$. leprae}

Results with either $\mathrm{NaOH}$-treated $M$. leprae, or $10 \mathrm{mM}$-UM-P or Casamino acids added to the incubation mixture, are presented separately only if either $\mathrm{CO}_{2}$ evolution or assimilation were significantly $(P<0.05)$ different in incubations with untreated bacteria without UM-P or Casamino acids. Substrate concentration was $0.02 \mathrm{~mm}$ except for incubations with glucose, glycerol and 6-phosphogluconate, which were also tested at $0.1 \mathrm{~mm}$. At the concentrations tested, substrate concentration did not affect $\mathrm{CO}_{2}$ evolution or assimilation. At least four controls and five tests were done for each incubation mixture. Where $M$. leprae were harvested from different tissues, the tests described above were done for each (up to three) tissue. No significant differences were observed between metabolic activities in $M$. leprae from different tissues.

Incubation mixture

Glucose

Glucose

Glucose + Casamino acids

Glucose + Casamino acids

Glycerol

Glucose-6-phosphate

Glucose-6-phosphate + UM-P

6-Phosphogluconate

6-Phosphogluconate + UM-P

6-Phosphogluconate, $\mathrm{NaOH}$ -

treated $M$. leprae

Gluconate

Gluconate

Gluconate + Casamino acids

\section{Incubation period}

(h)

20

140

20

140

20

20

20

20

20

20

\section{0}

140

140
Radioactivity

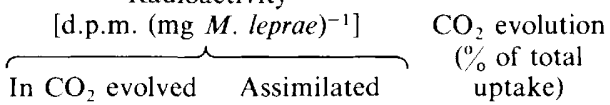

ND, Not determined.

suspensions was completely inhibited by $10 \mathrm{~mm}-\mathrm{UM}-\mathrm{P}$. In incubations for $20 \mathrm{~h}$ with either $0.02 \mathrm{~mm}$-glucose 6-phosphate or 6-phosphogluconate and $1 \mathrm{mg} \mathrm{M}$. leprae, $60 \%$ of the $10 \mathrm{~mm}$ UM-P was hydrolysed to 4-methylumbelliferone.

Since 6-phosphogluconate was a good substrate for oxidation by $M$. leprae, gluconate oxidation was studied. Over $20 \mathrm{~h}$ very little gluconate was oxidized to $\mathrm{CO}_{2}$ and the proportion taken up that was oxidized was also low (Table 1). When the incubation mixture was supplemented with $1 \%(\mathrm{w} / \mathrm{v})$ Casamino acids (Difco), no significant difference in assimilation or $\mathrm{CO}_{2}$ production from gluconate was observed.

Some $140 \mathrm{~h}$ incubations were carried out, with gluconate or glucose \pm Casamino acids. Compared with $20 \mathrm{~h}$ incubations, gluconate oxidation to $\mathrm{CO}_{2}$ was increased fivefold, and assimilation increased eightfold, but when Casamino acids were included in the incubation mixture (Table 1), the increase was only threefold for both oxidation and assimilation. The inhibition of assimilation of gluconate by Casamino acids was statistically significant $(P<$ $0 \cdot 05)$. Glucose oxidation to $\mathrm{CO}_{2}$ and assimilation were both significantly depressed $(P<0.05$ in all cases) by Casamino acids in $20 \mathrm{~h}$ and $140 \mathrm{~h}$ incubations. Similar increases in oxidation and assimilation in $140 \mathrm{~h}$ incubations compared with $20 \mathrm{~h}$ incubations were observed with glucose as with gluconate (Table 1).

Key enzymes of glucose metabolism by glycolysis

Hexokinase. Glucose actually inhibited oxidation of NADH when a coupled assay system for ADP was used to detect hexokinase in extracts, so glucose 6-phosphate was used to inhibit hexokinase (Hammes \& Kochavi, 1962) in controls instead of omitting hexoses. Although hexokinase could be measured in extracts of $M$. leprae by detecting glucose 6-phosphate formed by coupling the reaction with glucose-6-phosphate dehydrogenase and measuring NADPH formation, measurement of the ADP formed was more useful because phosphorylation of different D-hexoses could be compared (measurements of activity with glucose by the two methods were in agreement). Relative rates of phosphorylation of glucose : deoxyglucose : gluco- 


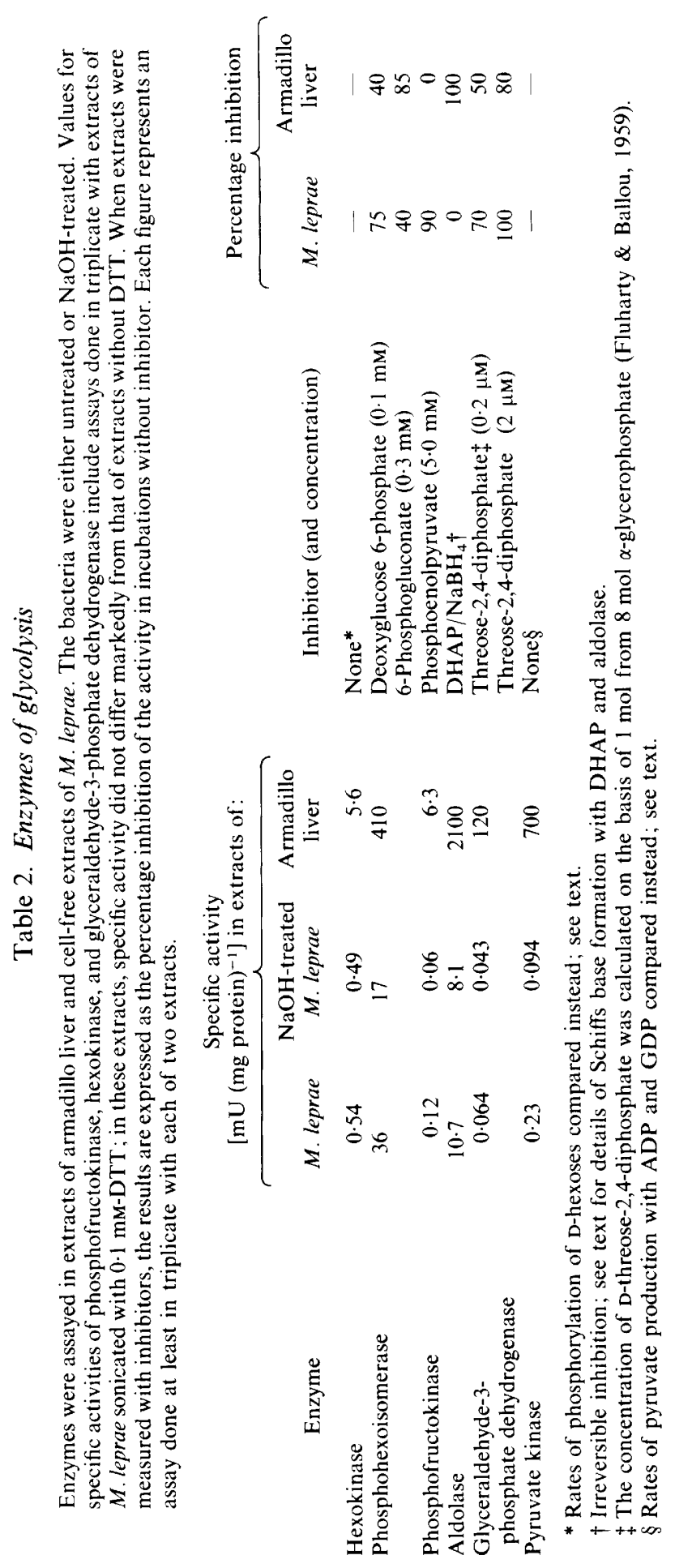


samine were 100:71:72 for $M$. leprae and 100:92:84 for armadillo liver extracts. Loss of activity (35\% loss) from both bacterial and liver extracts was observed after freezing and thawing.

Phosphohexoisomerase. With fructose 6-phosphate as the substrate, no increase in $A_{340}$ was observed if yeast 6-phosphogluconate dehydrogenase (Sigma $1 \mathrm{U} \mathrm{ml}^{-1}$ ) was added to the incubation mixture, for extracts of either $M$. leprae or armadillo tissues (liver or lymph node). Therefore, specific activities were calculated on the basis of 2 mol NADP reduced (mol fructose 6-phosphate isomerized $)^{-1}$. Phosphohexoisomerase was not inhibited by phosphoenolpyruvate (up to $5 \mathrm{~mm}$ ), but it was inhibited by 2-deoxy-D-glucose (Wick et al., 1957). Differential inhibition of the enzyme in extracts of armadillo liver and $M$. leprae was observed with 2deoxyglucose at $1.0 \mathrm{~mm}$ (Table 2), but not at $0.2 \mathrm{~mm}$ (only $25-30 \%$ inhibition).

With D-glucose 6-phosphate as substrate, rates of enzyme activity were similar to those observed with fructose 6-phosphate. 6-Phosphogluconate (Kahana et al., 1960), at $0.3 \mathrm{mM}$, inhibited the enzyme from armadillo tissues more strongly than the enzyme from extracts of $M$. leprae (Table 2).

Phosphofructokinase. ITP (inosine triphosphate) was as effective a substrate for armadillo liver phosphof ructokinase as ATP, but the enzyme in extracts of $M$. leprae used ITP at only $25 \%$ the rate of ATP. Inhibition of phosphofructokinase by $5 \mathrm{~mm}$-phosphoenolpyruvate (Yoshida $e t$ al., 1971) was far stronger in extracts of $M$. leprae than in extracts of armadillo liver (Table 2); at $1 \mathrm{mM}$ it inhibited the activity in extracts of $M$. leprae by $60 \%$.

If EDTA-treated liver extract was used, the specific activity was $<0.5 \%$ of the value in Table 2. Cell-free extracts from EDTA-treated $M$. leprae contained $0.095 \mathrm{mU}$ phosphofructokinase $(\mathrm{mg} \text { protein })^{-1}$.

The enzyme in $M$. leprae and liver extracts had, respectively, $2 \cdot 2$-fold and 2 -fold greater activity at $34{ }^{\circ} \mathrm{C}$ than at $22^{\circ} \mathrm{C}$. In all extracts assayed, the rate of phosphorylation of D-fructose 6-phosphate increased with time up to $100 \mathrm{~min}$ for $M$. leprae extracts and $10 \mathrm{~min}$ for liver extracts. Specific activities (Table 2) were calculated after incubations of $60 \mathrm{~min}$ and $6 \mathrm{~min}$, respectively.

Aldolase. The ratio of enzyme activity at $\mathrm{pH} 8.6: \mathrm{pH} 7.6$ was 0.64 to 0.72 in extracts of $M$. leprae (including $\mathrm{NaOH}$-treated $M$. leprae). In extracts from armadillo tissues, the ratio was 3.72 for liver and 1.29 for lymph node.

Treating extracts with the substrate dihydroxyactetone phosphate (DHAP) in the presence of nascent hydrogen had a differential effect on aldolase in extracts of armadillo liver and in extracts of $M$. leprae (Table 2 ; the inhibitor is described as DHAP/NaBH$H_{4}$ ). The ratio of activity at $\mathrm{pH} 8 \cdot 6: 7.6$ was 0.61 in extracts of $M$. leprae treated with DHAP and $\mathrm{NaBH}_{4}$.

Glyceraldehyde-3-phosphate dehydrogenase. Reduction of 1,3-diphospho-D-glycerate could be followed in $M$. leprae extracts for $60 \mathrm{~min}$ at $22^{\circ} \mathrm{C}$ but only $20 \mathrm{~min}$ at $34^{\circ} \mathrm{C}$, after which time the rate of reaction had fallen considerably compared with the initial velocity. D-Threose $2,4-$ diphosphate (Fluharty \& Ballou, 1959), prepared from glycolaldehyde phosphate (Loring et al., 1956), inhibited the enzyme in extracts of $M$. leprae more strongly than the enzyme in extracts of armadillo liver (Table 2).

Pyruvate kinase. The activity of this enzyme with GDP was $85 \%$ of that obtained with ADP in extracts of armadillo liver. The enzyme could not be detected in $M$. leprae when GDP was substituted for ADP.

\section{Key enzymes of 'alternative' metabolic pathways, including glycerol catabolism}

Glucose-6-phosphate dehydrogenase. This enzyme was found in each of seven extracts of $\boldsymbol{M}$. leprae and was present in one extract (Ex 146) of untreated $M$. leprae at about $10 \%$ the activity in all other extracts (Table 3). EDTA- and $\mathrm{NaOH}$-treatment of $M$. leprae did not affect the enzyme activity. Enzyme activities in extracts of armadillo liver homogenized in phosphate $/ \mathrm{MgCl}_{2}$ (Table 3) and in extracts of infected liver, which was homogenized in Tris, were similar. The enzyme in $M$. leprae extracts could be incubated at $\mathrm{pH} 9 \cdot 2$ in triethanolamine $/ \mathrm{HCl}$ for $1 \mathrm{~h}$ and retained full activity (the assay was performed after adjusting the $\mathrm{pH}$ to 7.6 with $\mathrm{HCl}$ ), and was suitable for electrophoresis in the system of Davis (1964). The electrophoretic mobilities of the 


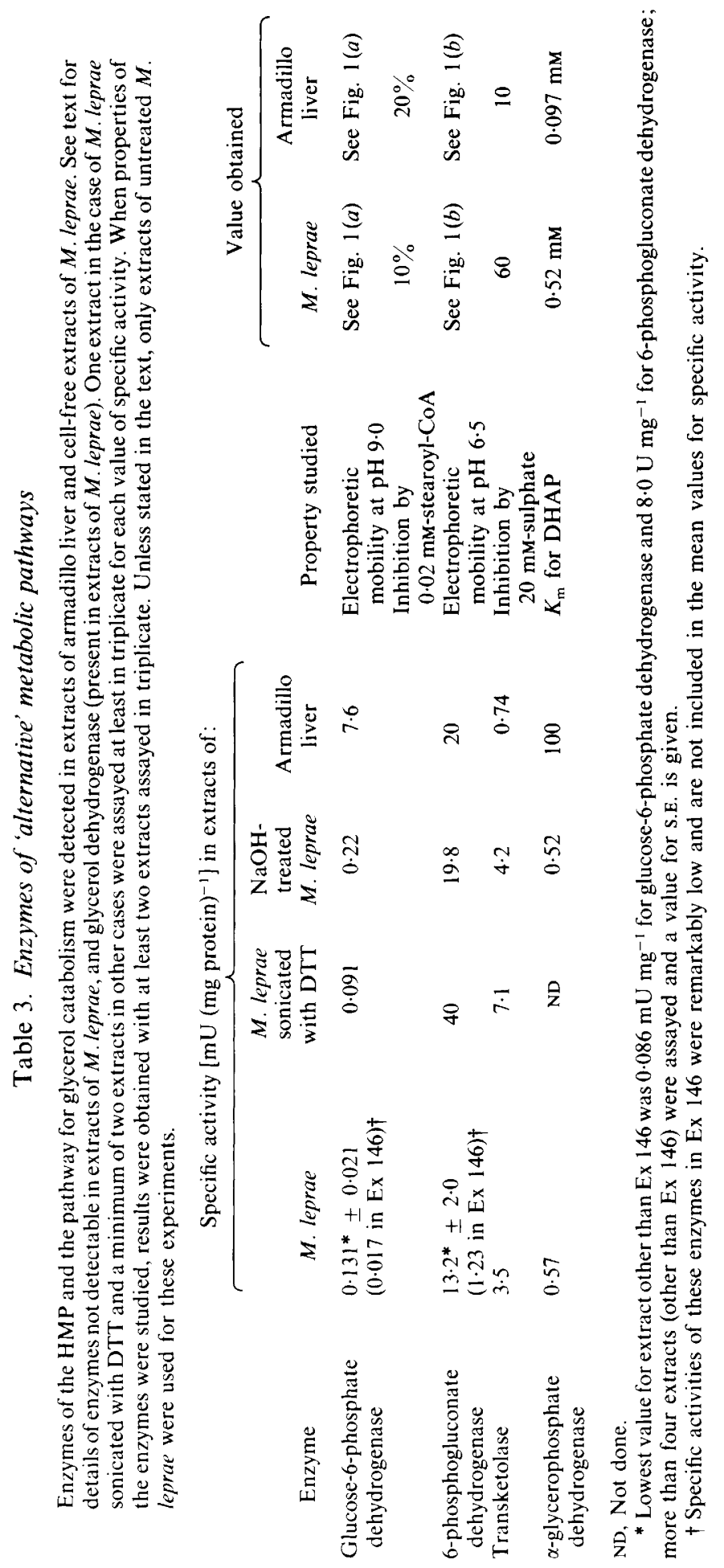




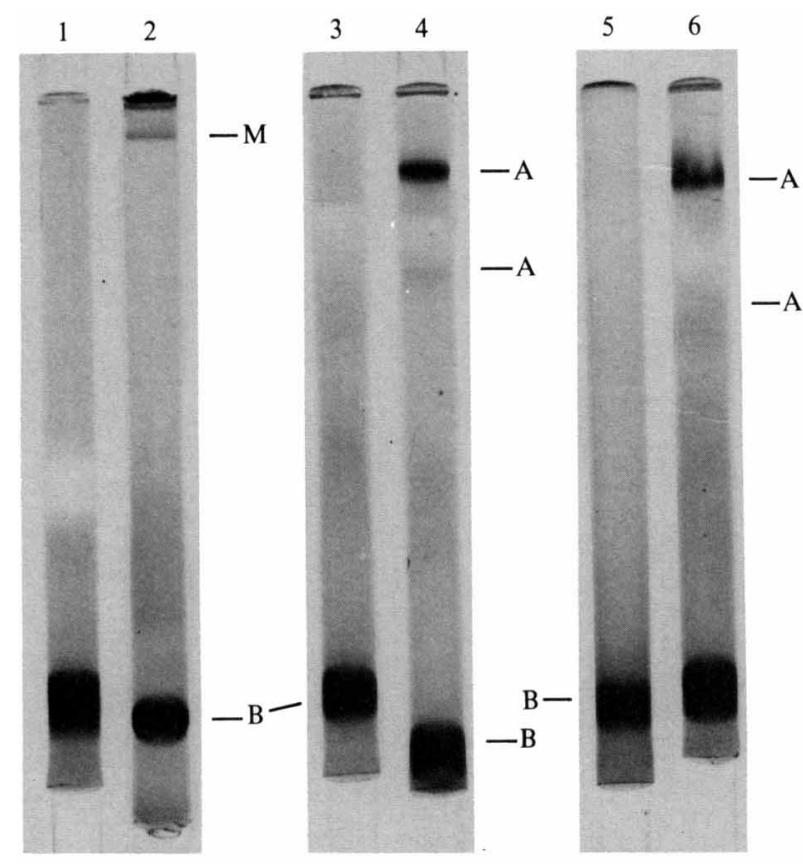

(a)

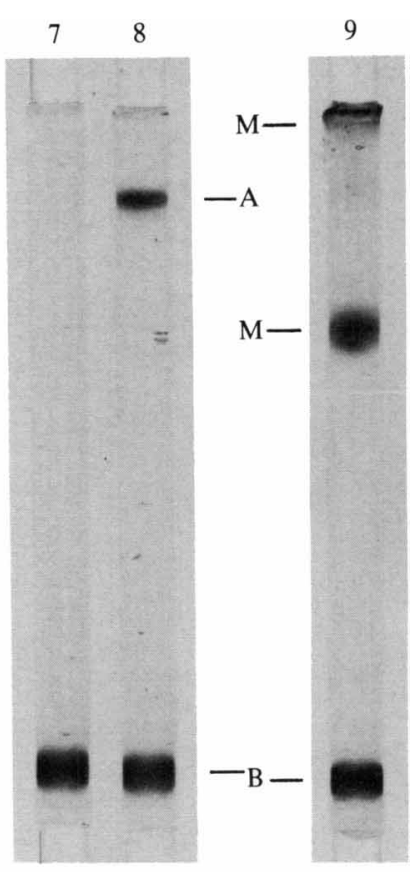

(b)

Fig. 1. PAGE of extracts on gels with different pH. (a) $\mathrm{pH} 9.0$ gels were stained for glucose-6phosphate dehydrogenase (tracks 2, 4,6) and compared with controls (tracks 1, 3, 5). The stain was made up without glucose 6-phosphate. Extracts were from: $M$. leprae (tracks 1,2); uninfected armadillo liver (tracks 3, 4); infected armadillo liver (tracks 5, 6). (b) pH 6.5 gels were stained for 6phosphogluconate dehydrogenase (tracks 8,9 ) and compared with a control (track 7). The stain was made up without 6-phosphogluconate. Extracts were from: $M$. leprae (track 9); uninfected armadillo liver (tracks 7,8). No bands were detected in the control with $M$. leprae extracts. Specific activity of the enzyme in infected armadillo liver extract was too low for electrophoresis. M denotes enzyme from $M$. leprae; A denotes enzyme from armadillo liver; B denotes bromophenol blue (marker).

enzymes in extracts of infected liver were the same as in extracts of uninfected tissue $(0.7 \mathrm{mU}$ of each applied to each gel) and clearly distinct from the enzymes in extracts of $M$. leprae (Fig. $1 a$ ). The enzyme from both sources was unable to use NAD instead of NADP and was not strongly inhibited by up to $0.02 \mathrm{mM}$-stearoyl-CoA (Neufeldt et al., 1965). For the incubations with stearoyl-CoA, extracts were preincubated with $0.2 \mathrm{~mm}$-phenylmethylsulphonyl fluoride (from a $20 \mathrm{~mm}$ stock solution in acetone) to inactivate esterases (Fahrney \& Gold, 1963) present (unpublished results). The ratio of activity at $34{ }^{\circ} \mathrm{C}$ to $22^{\circ} \mathrm{C}$ was $3.5 \mathrm{in} M$. leprae extracts and 3.8 in armadillo liver extracts. The enzyme was also detected in extracts of $M$. lepraemurium, at $0.41 \mathrm{mU}(\mathrm{mg} \text { protein })^{-1}$.

6-Phosphogluconate dehydrogenase. Like glucose-6-phosphate dehydrogenase, this enzyme was present at a very low specific activity in Ex 146 relative to the specific activity in six other extracts of $M$. leprae (Table 3). Such very low enzyme activities in Ex 146 were confined to these two enzymes: phosphofructokinase and glyceraldehyde-3-phosphate dehydrogenase were present in Ex 146 at levels similar to the mean values in Table 2 (lack of material restricted further assays on Ex 146).

EDTA- and $\mathrm{NaOH}$-treatment of $M$. leprae organisms did not affect 6-phosphogluconate dehydrogenase but, after incubation of extracts of $M$. leprae at $\mathrm{pH} 9 \cdot 2$ (as described in previous section), only $5 \%$ of the 6 -phosphogluconate dehydrogenase activity remained. Activity of the enzyme from $M$. leprae or armadillo liver could not be detected on polyacrylamide gels run at pH 9.0 (Davis, 1964) so the method of Chang et al. (1979) was used. The mobility of the one band 
of enzyme activity from host-liver ( $1 \mathrm{mU}$ applied to each gel) was distinct from 6phosphogluconate dehydrogenase from $M$. leprae (Fig. $1 b$ ).

In extracts of $M$. leprae, 6-phosphogluconate dehydrogenase was found at levels one hundred times greater than glucose-6-phosphate dehydrogenase (Table 3). This may be an underestimate, since an even higher level of activity (Table 3 ) was observed in extracts of $M$. leprae if $0.1 \mathrm{~mm}$ DTT was added to the sonication buffer. The enzyme was present at $0.54 \mathrm{mU}$ (mg protein $)^{-1}$ in extracts of $\boldsymbol{M}$. lepraemurium.

Transketolase. The specific activity of transketolase in extracts was high relative to many other enzymes from $M$. leprae and was elevated when $0.1 \mathrm{mM}$-DTT was present in the sonication buffer for $M$. leprae (Table 3); enzyme activity in extracts of $M$. leprae was similar with erythrose 4-phosphate or ribose 5-phosphate as a substrate. The enzyme in $M$. leprae extracts was more strongly inhibited by $\mathrm{Na}_{2} \mathrm{SO}_{4}$ than the enzyme in extracts of armadillo liver (Table 3 ).

$\alpha$-Glycerophosphate dehydrogenase. Experiments with inhibitors of this enzyme were impracticable; for instance, high levels of aldolase in extracts would interfere with fructose 1,6diphosphate, a possible allosteric inhibitor (Beisenhertz et al., 1953). However, a difference in affinity for DHAP was observed between the enzyme in extracts of $M$. leprae and armadillo liver. With $2.1 \mathrm{~mm}$-DHAP, the enzyme activity at $34^{\circ} \mathrm{C}$ in extracts of $M$. leprae was $50 \%$ greater than at $22^{\circ} \mathrm{C}$. This enzyme was also detected in both extracts with $\alpha$-glycerophosphate as a substrate (Winder \& Brennan, 1966).

Glycerol dehydrogenase. This enzyme was present at a specific activity of $0.11-0.14 \mathrm{mU}(\mathrm{mg}$ protein $)^{-1}$ in extracts of untreated and $\mathrm{NaOH}$-treated $M$. leprae: a lower level, $0.04 \mathrm{mU}(\mathrm{mg}$ protein $)^{-1}$ was found in armadillo liver extracts. The tetrazolium salt in the assay could be reduced directly even in desalted (Amicon CF25 cone) extracts, but in vivo it is likely that NAD or NADP was reduced (Winder \& Brennan, 1966). Specific activities were too low for gel electrophoresis, although the assay could have been used directly to detect the enzyme on gels.

\section{Enzymes not detectable in extracts of $M$. leprae}

Phosphoketolase, glucuronate reductase, gluconate phosphotransferases (with ATP or tetrapolyphosphate), enzymes for direct oxidation of glucose to gluconate (Chedelin, 1961; Galante et al., 1963), and the EDP enzymes could not be detected in extracts of M. leprae, even when $0.1 \mathrm{~mm}$-DTT was included in the sonication buffer. The lowest specific activities that could be detected were $5 \mu \mathrm{U}(\mathrm{mg} \text { protein })^{-1}$ for phosphoketolase, glucose oxidase, glucose dehydrogenase and the EDP enzymes and, using the cycling method for NADP, $0.3 \mu \mathrm{U}(\mathrm{mg}$ protein $)^{-1}$ for gluconate kinase and $0 \cdot 9 \mu \mathrm{U}(\mathrm{mg} \text { protein })^{-1}$ for glucuronate reductase. Gluconate kinase was detected in extracts of $M$. phlei.

\section{DISCUSSION}

Mycobacterium leprae catabolizes glucose by glycolysis and the HMP. The proportion of glucose catabolized by the HMP is as high as previously observed for other mycobacteria (Bai $e t$ al., 1975b, 1976; O'Barr \& Rothlauf, 1970; Ramakrishnan et al., 1972). The values for the proportion of glucose catabolized by the HMP in the work of Bai et al. $(1975 b, 1976)$ can be recalculated by the method of Wood et al. (1963). If this is done, the maximum value for catabolism through the pentose cycle (Wood et al., 1963) observed in their work is $9.2 \%$. In contrast to $M$. leprae, this study confirmed that $M$. lepraemurium does not use glucose very effectively as a substrate for oxidation (Tepper \& Varma, 1972).

All enzymes detected in extracts of $M$. leprae had properties different from similar enzymes in liver extracts. Differences in substrate-specificity or affinity, the effects of inhibitors, or electrophoretic mobility were detected. From these results, all the enzymes discussed were authentic $M$. leprae enzymes. Additionally, after treatment of $M$. leprae with $\mathrm{NaOH}$ (Wheeler $e t$ al., 1982) or EDTA (Brock, 1969) to inactivate any host-enzymes which may have been adsorbed to the surface, all of the enzymes could still be detected in extracts from the treated bacteria. Where electrophoretic analysis was possible it was possible to show that $M$. leprae glucose-6- 
phosphate dehydrogenase was not present in extracts of infected tissues after the bacteria had been removed.

The properties of some enzymes were of particular interest. Some of the enzyme inhibitors, e.g. 6-phosphogluconate against phosphohexoisomerase (Kahana et al., 1960), phosphoenolpyruvate against phosphofructokinase (Yoshida et al., 1971), and stearoyl-CoA against glucose6-phosphate dehydrogenase (Neufeldt et al., 1965), are known to regulate enzyme activity and may do so in $M$. leprae. Nucleotide requirements of pyruvate kinase and phosphofructokinase of $M$. leprae were more specific than those of the armadillo liver enzymes. Phosphorylation of hexoses was attributed to hexokinase but an ATP :glucose phosphotransferase (glucokinase) may be present: this possibility does not diminish the evidence for an authentic $M$. leprae hexokinase since the relative rates of phosphorylation of glucosamine and deoxyglucose are different in extracts from $M$. leprae and host tissues. Conversely, the glucokinase reported in crude extracts of some mycobacteria (Bai et al., 1975 b, 1976) could be hexokinase. Mycobacterium leprae, like $M$. tuberculosis (Bai et al., 1975a) has a class II fructose-diphosphate aldolase. In contrast, host tissue has a class I aldolase. Generally, class I is mammalian and class II is bacterial (Rutter, 1964). Unlike the aldolase of $M$. tuberculosis $\mathrm{H}_{37} \mathrm{Rv}$ (Bai et al., 1975a), and the armadillo enzyme, $M$. leprae aldolase had higher activity at $\mathrm{pH} 7 \cdot 6$ than $\mathrm{pH} 8 \cdot 6$.

Glycerol is a good substrate for oxidation by $M$. leprae, like other mycobacteria. The key enzyme of glycerol catabolism, $\alpha$-glycerophosphate dehydrogenase (Hunter, 1953) was detected in extracts of $M$. leprae, but glycerol dehydrogenase was also detected. Thus, $M$. leprae can reduce glycerol either directly or after phosphorylation like $M$. smegmatis (Hunter, 1953) and old cultures of $M$. tuberculosis BCG (Winder \& Brennan, 1966), but unlike other mycobacteria (including, otherwise, BCG). The metabolite DHAP could then be metabolized further by the Embden-Meyerhof Pathway.

The assay of enzymes in crude extracts has provided much information about mycobacterial metabolism (e.g. Bai et al., 1975b, 1976). In this study, substrates for the enzymes were used at saturating concentrations. Any substrate removed by interfering enzymes in the extracts did not affect the rate of the reaction being studied. During the incubations of extracts (5-15 min for armadillo, 15-60 min for $M$. leprae), after a lag phase in some cases, the rate of reaction was generally linear. However, with $M$. leprae glyceraldehyde-3-phosphate dehydrogenase, the rate fell with time: this enzyme proved to be unstable, particularly at $34^{\circ} \mathrm{C}$. With some enzymes, the rate increased throughout the incubation period; this may have been due to the removal of substrate-inhibition or even stimulation by the product, as reported for phosphofructokinase (Ramaiah et al., 1964). Studies with inhibitors were done only if they were not metabolized by interfering enzymes. Therefore, incubations with inhibitors were considered to distinguish reliably bacterial from host-tissue enzymes and the specific activities were a reliable guide to enzyme activities in $M$. leprae.

While activities of individual enzymes were very different in $M$. leprae, this was also seen in M. smegmatis (Bai et al., 1976) and M. tuberculosis (Bai et al., 1975 b; Bastarrachea et al., 1961). Activities of enzymes in extracts of $M$. leprae relative to $M$. tuberculosis $\mathrm{H}_{37} \mathrm{Rv}$ (Bai et al., 1975b) or $\mathrm{H}_{37} \mathrm{Ra}$ (Bastarrachea et al., 1961) were between 0.4 and $1.5 \%$ for phosphofructokinase, pyruvate kinase and glucose-6-phosphate dehydrogenase; between 9 and $17 \%$ for phosphohexoisomerase, hexokinase and aldolase, and the activity of $\alpha$-glycerophosphate dehydrogenase was $23 \%$ of the activity in extracts of $M$. tuberculosis BCG (Winder \& Brennan, 1966). The activity of 6-phosphogluconate dehydrogenase was $143 \%$ of the activity in extracts of $M$. tuberculosis $\mathrm{H}_{37} \mathrm{Rv}$ (Bai et al., 1975b). 6-Phosphogluconate dehydrogenase activity in $M$. smegmatis (Bai et al., 1976), M. tuberculosis $\mathrm{H}_{37} \mathrm{Rv}$ (Bai et al., 1975b) and M. lepraemurium was almost the same as glucose-6-phosphate dehydrogenase activity, but in $M$. leprae it was 100 times higher. The results obtained with the two HMP enzymes in $M$. leprae suggest that the enzyme at low activity, glucose-6-phosphate dehydrogenase, was less labile to the manipulations in this work. So the difference in specific activities could not be explained by differential denaturation. The observation that $M$. leprae used 6-phosphogluconate most efficiently as a source for oxidation (measured by $\mathrm{CO}_{2}$ production) suggested that there is a metabolic significance in the elevated activity of 6-phosphogluconate dehydrogenase. 
It may be that $M$. leprae scavenges 6-phosphogluconate, which may be available as a byproduct of the metabolism of activated macrophages (Karnovsky et al., 1975), in which $M$. leprae resides. It is interesting that the obligate intracellular parasites, Plasmodium spp., which have no glucose-6-phosphate dehydrogenase but do have 6-phosphogluconate dehydrogenase, may scavenge 6-phosphogluconate produced by host erythrocytes (Sherman, 1979).

Enhancement of 6-phosphogluconate oxidation by UM-P was far greater than expected by its effect of inhibiting the limited hydrolysis of the substrate by acid phosphatase. Indeed, UM-P had an opposite effect on uptake and oxidation of glucose 6-phosphate by $M$. leprae. These results may represent a difference in metabolic control, or uptake of the sugar-phosphates, mediated by UM-P (or umbelliferone). Neither sodium nor potassium ions affected assimilation or $\mathrm{CO}_{2}$ evolution with either sugar-phosphate (unpublished results) suggesting that a sodiumdependent transport system for sugar-phosphates (Roseman, 1977) was not operating in $M$. leprae. The difference between glucose and glucose 6-phosphate uptake (in untreated $M$. leprae) may reflect differences in the uptake mechanisms; their metabolism, measured as proportions oxidized and assimilated, was very similar.

Since gluconate catabolism is inducible in some other mycobacteria (Szymona et al., 1969), this might have explained why it was a poor substrate for oxidation for $M$. leprae. When Casamino acids were added to the incubation medium, and when the incubation period was extended, gluconate catabolism may have been induced. However, the amino acids inhibited oxidation of ${ }^{14} \mathrm{C}$-labelled substrates to $\mathrm{CO}_{2}$ and may have been acting as carbon sources themselves. The absence of any gluconate-phosphorylating activity in $M$. leprae suggested that the role of the high level of 6-phosphogluconate dehydrogenase does not play a part in gluconate catabolism.

The low levels of HMP enzymes in Ex 146 and not in any other extracts might be explained by an 'environmental' effect, since some of the other extracts were made from $M$. leprae grown in other armadillos but from the same inoculum as Ex 146. Unfortunately, it is impossible to plan experiments on induction of metabolic activities by $M$. leprae at the moment since there is only one practicable (in vivo) source of the bacteria for biochemical studies.

Mycobacterium leprae, on the basis of these results, can use glucose and glycerol as energy sources, like many other mycobacteria, and also 6-phosphogluconate. Some negative results are of interest: the absence of both glucuronate reductase and EDP activity indicate that glucuronate cannot be used as an energy source by $M$. leprae. This is important because hyaluronic acid has been suggested as a growth substrate for $M$. leprae (Matsuo \& Skinsnes, 1974) on the basis of the detection of glycosidases, which would be part of a pathway of hyaluronic acid dissimilation. However, hyaluronic acid is not oxidized by suspensions of $M$. lepraemurium (Kato et al., 1976), and, although the presence of the glycosidases has been confirmed (Wheeler $e t$ al., 1982), it is shown in this study that key enzymes for the breakdown of one of the products of the glycosidases are absent in $M$. leprae.

I thank R. J. W. Rees and P. Draper for helpful discussions and D. W. Gregory for technical assistance. LEPRA (British Leprosy Relief Association) provided funds for maintaining the colony of armadillos.

\section{REFERENCES}

AmEs, B. N. (1966). Assays of inorganic phosphate, total phosphate, and phosphatases. Methods in Enzymology 8, 115-118.

Bai, N. J., Pai, M. R., Murthy, P. S. \& VenkitasuBramanian, T. A. (1975a). Fructose-1,6-diphosphate aldolase of Mycobacterium tuberculosis $\mathrm{H}_{37} \mathrm{Rv}$. Indian Journal of Biochemistry and Biophysics 12, 181182.

Bai, N. J., Pai, M. R., Murthy, P. S. \& VenkitasuBramanian, T. A. (1975b). Pathways of carbohydrate metabolism in Mycobacterium tuberculosis $\mathrm{H}_{37} \mathrm{Rv}$. Canadian Journal of Microbiology 21, 16881691.
Bai, N. J., Pai, M. R., Murthy, P. S. \& VenkitasuBRamanian, T. A. (1976). Pathways of glucose catabolism in Mycobacterium smegmatis. Canadian Journal of Microbiology 22, 1374-1380.

Bastarrachea, F., Anderson, D. G. \& Goldman, D. S. (1961). Enzyme systems in mycobacteria. IX. Glycolytic system in Mycobacterium tuberculosis. Journal of Bacteriology 82, 94-101.

Beisenhertz, G., Boltze, H. J., Bucher, T., Czok, R., Garbade, K. H., Meyer-Arendt, E. \& Pfleiderer, G. (1953). Diphosphofructose-aldolase, Phosphoglyceraldehyd-dehydrogenase, Milchsäuredehydrogenase, Glycerophosphat-dehydrogenase 
und Pyruvatkinase aus Kaninchenmuskulatur in einem Arbeitsgang. Zeitschrift für Naturforschung 8B, 555-577.

BENSON, A. A. (1957). Sugar phosphates; paper and column chromatography. II. Exchange resin chromatography of sugar phosphates. Methods in Enzymology 3,121-129.

Bergmeyer, H. U., Gawehn, K. \& Grassl, M. (1974). Enzymes as biochemical reagents. In Metabolic Enzlme Analysis, vol. 1, 2nd English edn, pp. 425522. Edited by H. U. Bergmeyer. London \& New York: Academic Press.

Brock, D. J. H. (1969). Purification and properties of sheep liver phosphofructokinase. Biochemical Journal 113, 235-242.

Brown, W. (1970). The selectivity of polyacrylamide gels for sugars. Journal of Chromatography 53, 572 575.

Chang, P. L., Ballantyne, S. R. \& Davidson, R. G (1979). Detection of arylsulphatase-A activity, after electrophoresis in polyacrylamide gel electrophoresis: problems and solutions. Analytical Biochemistry 97, 36-42.

Chedelin, V. H. (1961). The acetic acid bacteria. In Metabolic Pathways in Microorganisms. E. R. Squibb Lectures on Chemistry of Microbial Products, pp. 129. New York: Wiley.

Colquhoun, D. (1971). Numerical and rank measurements. In Lectures on Biostatistics, pp. 137-151. Oxford: Clarendon Press.

Davis, B. J. (1964). Disc electrophoresis. II. Method and application to human serum protein. Annals of the New York Academy of Sciences 121, 404-427.

FaHRNeY, D. E. \& Gold, A. M. (1963). Sulfonyl fluorides as inhibitors of esterases. I. Rates of reaction with acetylcholinesterase, $\alpha$-chymotrypsin and trypsin. Journal of the American Chemical Society 85, 997-1000.

Fluharty, A. V. \& Ballou, C. E. (1959). D-threose2.4-diphosphate inhibition of D-glyceraldehyde-3phosphate dehydrogenase. Journal of Biological Chemistry 234, 2517-2522.

Galante, E., Scalaffa, P. \& Lanzari, G. A. (1963). Attività enzymatiche di Acetobacter suboxydans. I. Glucosiodeidrogenasi. Enzymologia 26, 23-30.

Goldberg, M., Fessenden, J. M. \& Racker, E. (1968). Phosphoketolase. Methods in Enzymology 9 , $515-520$.

Grazi, E., Cheng, T. \& Horecker, B. L. (1962). The formation of a stable aldolase-DHAP complex. Biochemical and Biophysical Research Communications 7 , 250-253.

Hammes, G. G. \& Kochavi, D. (1962). Studies of the enzyme hexokinase. II. Kinetic inhibition by products. Journal of the American Chemical Society 84 , 2073-2076

Horecker, B. L., Smyrniotis, P. Z. \& Hurwitz, J. (1956). The role of xylulose 5-phosphate in the transketolase reaction. Journal of Biological Chemistr. 223, 1009-1019.

Hunter, B. J. (1953). The oxidation of glycerol by mycobacteria. Biochemical Journal 55, 320-328.

Kahana, S. E., Lowry, O. H., Schulz, D. S., Passonneau, J. V. \& Crawford, E. J. (1960). The kinetics of phosphoglucoisomerase. Journal of Biological Chemistry 235, 2178-2184.
KaRnOVSKY, M. L., LAZDINS, J., DRATH, D. \& HARPER, A. (1975). Biochemical characteristics of activated macrophages. Annals of the New York Academy of Sciences 256, 266-274

Kato, L., Adapoe, C. \& Ishaque, M. (1976). The respiratory metabolism of Mycobacterium lepraemurium. Canadian Journal of Microbiology 22, 12931299.

Khanolkar, S. R. (1982). Preliminary studies of metabolic activity of purified suspensions of $\mathrm{Myco}$ bacterium leprae. Journal of General Microbiology 128, 423-425.

Kirchheimer, W. F. \& StorRs, E. E. (1971). Attempts to establish the armadillo (Dasvpus novemcinctus Linn.) as a model for the study of leprosy. I. Report of lepromatoid leprosy in an experimentally infected armadillo. International Journal of Leprosv 39, 693702.

Kovachevich, R. \& Wood, W. A. (1955), Carbohydrate metabolism by Pseudomonas fuorescens. III. Purification and properties of a 6-phosphogluconate dehydrase. Journal of Biological Chemistry 213, 745 756.

Kusunose, E., Kusunose, M., IChihara, K. \& Izumi, S. (1980). Occurrence of superoxide dismutase in Mycobacterium leprae grown in armadillo liver. Journal of General and Applied Microbiology 26, 369372.

Lilius, E.-M., Multanen, V.-M. \& Toivonen, V. (1979). Quantitative extraction and estimation of intracellular nicotinamide nucleotides of Escherichia coli. Analytical Biochemistry 99, 22-27.

Ling, K. H., PaetKan, V., Marcus, F. \& Lardy, H. A. (1966). Phosphofructokinase. Methods in Enzymology 9, 425-429.

Loring, R. S., Levy, L. W., Moss, L. K. \& Ploeser, J. M. (1956). Periodate oxidation of sugar phosphates in neutral solution. I. D-Ribose 5-phosphate. Journal of the American Chemical Society 78, 37243727.

Matsuo, E. \& Skinsnes, O. K. (1974). Acid mucopolysaccharide metabolism in leprosy. 2. Subcellular localization of hyaluronic acid and $\beta$-glucuronidase in leprous infiltrates suggestive of a host- $\mathrm{Myco}$ bacterium leprae metabolic relationship. International Journal of Leprosy 42, 399-4l1.

Menzies, I. S. \& Seakins, J. W. T. (1969). In Chromatographic and Electrophoretic Techniques, vol I, p. 313. Edited by 1. Smith. New York: Interscience.

Mori, S. H., Kamada, I. \& Matsui, S.-I. (1967). Electrophoretic separation of the magnesium-dependent glucose 6-phosphate dehydrogenase in rats. Journal of Histochemistry and Cytochemistry 15, 419420 .

Neufeldt, I. E., Teinzer, A., Weiss, L. \& Wieland, O. (1965). Inhibition of glucose-6-phosphate dehydrogenase by long chain acyl-coenzyme A. Biochemical and Biophysical Research Communications 19 . $43-48$

Nimmo, I. A. \& Atkins, G. L. (1979). The statistical analysis of non-normal (real?) data. Trends in Biochemical Science 4, 236-239.

O'BARR, T. P. \& Rothlauf, M. V. (1970). Metabolism of D-glucose by Mycobacterium tuberculosis. American Review of Respiratory Disease 101, 964-966. 
PrabhakaRAN, K. (1973). DOPA metabolism by Mycobacterium leprae: its implications in culture of the bacillus and chemotherapy of leprosy. Leprosy Review 44, 112-119.

Prabhakaran, K. \& Braganca, B. M. (1962). Glutamic acid decarboxylase activity of $\mathrm{Myco}$ bacterium leprae and occurrence of $\alpha$-aminobutyric acid in skin lesions of leprosy. Nature, London 196, $589-590$.

Ramaiah, A., Hathway, J. A. \& Atkinson, D. E. (1964). Adenylate as a metabolic regulator. Journal of Biological Chemistry 239, 3613-3623.

RAMAKRISHNAN, T., MURTHY, P. S. \& GopinathaN, K. P. (1972). Intermediary metabolism of mycobacteria. Bacteriological Reviews 36, 65-108.

RatledGe, C. (1976). The physiology of the mycobacteria. Advances in Microbial Physiology 13, 115244.

REPORT (1979). Problems related to purification of Mycobacterium leprae armadillo tissues and standardization of Mycohacterium leprae preparations. Report on the Enlarged Steering Committee Meeting, Geneva, 7-8 February, 1979, WHO Document TDR/IMMLEP.

Roseman, S. (1977). The transport of sugars across bacterial membranes. FEBS Symposium 42, 582597.

RutTer, W. J. (1964). Evolution of aldolase. Federation Proceedings 23, 1248-1257.

Sherman, I. W. (1979). Biochemistry of Plasmodium (malarial parasites). Microbiological Reviews 43, 453495.

Shetty, K. T., Antia, N. R. \& Krishnaswamy, P. R. (1981). Occurrence of $\gamma$-glutamyl transpeptidase activity in several mycobacteria including $\mathrm{Myco-}$ bacterium leprae. International Journal of Leprosy 49 , $49-56$.
Szymona, O., Kowalska, H. \& Szymona, M. (1969). Search for inducible sugar kinases in Mycobacterium phlei. Annals of the University of Marie CurieSklodowska, Lubin-Polonia, Sectio D 24, 1-12.

Tepper, B. S. \& VARMA, K. G. (1972). Metabolic activity of purified suspensions of Mycobacterium lepraemurium. Journal of General Microbiology 73, 143-152.

W HEELER, P. R. (1982). Metabolism of carbon-sources by Mycobacterium leprae. A preliminary report. Annales de Microbiologie 133B, 141-146.

WheEler, P. R. \& GRegory, D. (1980). Superoxide dismutase, peroxidatic activity and catalase in Mycobacterium leprae purified from armadillo liver. Journal of General Microbiology 121, 457-464.

WheEler, P. R., BharadwaJ, V. P. \& Gregory, D. (1982). $N$-Acetyl $\beta$-glucosamidase, $\beta$-glucuronidase and acid phosphatase in Mycobacterium leprae. Journal of General Microbiology 128, 1063-1071.

WICK, A. N., DruRY, D. R., NAKada, H. I. \& Wolfe, J. B. (1957). Localization of the primary metabolic block produced by 2-deoxyglucose. Journal of Biological Chemistry 224, 963-969.

WINDER, F. G. \& BRENNAN, P. J. (1966). Initial steps in the metabolism of glycerol by Mycohacterium tuberculosis BCG. Journal of Bacteriology 92, 1846-1847.

Wood, H. G., Katz, J. \& Landau, B. R. (1963). Estimation of pathways of carbohydrate metabolism. Biochemische Zeitschrift 338, 809-847.

York, J. L., Grollman, A. P. \& Bublitz, C. (1961). TPN-L-gulonate dehydrogenase. Biochimica et biophysica acta 47, 298-306.

Yoshida, M., Oshima, T. \& ImaHori, K. (1971). The thermostable allosteric enzyme: phosphofructokinase from an extreme thermophile. Biochemical and Biophysical Research Communications 43, 3639. 